\title{
Dependence of calcite growth rate and Sr partitioning on solution stoichiometry: Non-Kossel crystal growth
}

\author{
G. Nehrke ${ }^{\mathrm{a}, *}$, G.J. Reichart ${ }^{\mathrm{b}}$, P. Van Cappellen ${ }^{\mathrm{b}}$, C. Meile $^{\mathrm{c}}$, J. Bijma ${ }^{\mathrm{a}}$ \\ ${ }^{a}$ Alfred Wegener Institute for Polar and Marine Research, Am Handelshafen 12, D-27570 Bremerhaven, Germany \\ ${ }^{\mathrm{b}}$ Utrecht University, Faculty of Geosciences, Department of Earth Sciences, Geochemistry, P.O. Box 80021, 3508 TA Utrecht, The Netherlands \\ ${ }^{c}$ Department of Marine Sciences, University of Georgia, Athens, GA 30602, USA
}

Received 5 October 2006; accepted in revised form 6 February 2007; available online 12 February 2007

\begin{abstract}
Seeded calcite growth experiments were conducted at fixed $\mathrm{pH}(10.2)$ and two degrees of supersaturation $(\Omega=5,16)$, while varying the $\mathrm{Ca}^{2+}$ to $\mathrm{CO}_{3}{ }^{2-}$ solution ratio over several orders of magnitude. The calcite growth rate and the incorporation of $\mathrm{Sr}$ in the growing crystals strongly depended on the solution stoichiometry. At a constant degree of supersaturation, the growth rate was highest when the solution concentration ratio, $r=\left[\mathrm{Ca}^{2+}\right] /\left[\mathrm{CO}_{3}{ }^{2-}\right]$, equaled one, and decreased symmetrically with increasing or decreasing values of $r$. This behavior is consistent with the kink growth rate theory for non-Kossel crystals, assuming that the frequency factors for attachment to kink sites are the same for the cation and anion. Measured Sr partition coefficients, $D_{\mathrm{Sr}}$, ranged from 0.02 to 0.12 , and correlated positively with the calcite growth rate.
\end{abstract}

(c) 2007 Elsevier Ltd. All rights reserved.

\section{INTRODUCTION}

Calcite is one of the most abundant and reactive minerals at the Earth's surface. It is a major component of the global carbon budget (Morse and Mackenzie, 1990), and it affects the fate of many organic and inorganic constituents in the environment through sorption processes (Langmuir, 1997). Furthermore, calcite is an important industrial material, although its formation may represent a nuisance in industrial processes (scale formation). Many studies have been devoted to the effects of physico-chemical parameters, such as temperature, pressure, $\mathrm{pH}$, ionic strength and supersaturation, on the precipitation of calcite from aqueous solution, as well as on trace element partitioning and isotope fractionation during calcite formation (Rimstidt et al., 1998; Lemarchand et al., 2004).

A variety of studies have shown that the calcite growth rate influences the removal of aqueous trace metals which are incorporated as impurities into calcite during mineral

\footnotetext{
* Corresponding author. Fax: +49 47148312020.

E-mail address: Gernot.Nehrke@awi.de (G. Nehrke).
}

precipitation (Rimstidt et al., 1998). The concentrations of trace metals, e.g., $\mathrm{Mg}, \mathrm{Sr}$ or $\mathrm{Ba}$, in biogenic calcite are used as proxies for the reconstruction of past environmental conditions (e.g., Boyle, 1981, 1988; Lea and Boyle, 1989), whereas sorption to calcite may represent an important pathway for the immobilization of hazardous metals, e.g., Cd and radionuclides (Curti, 1997).

To capture the dynamics of calcite growth, kinetic descriptions based on classical crystal growth theory relate the rate of calcite precipitation to the degree of supersaturation, $\Omega=\mathrm{IAP} / K$, where $K$ is the solubility product of calcite, and IAP $=\left\{\mathrm{Ca}^{2+}\right\}\left\{\mathrm{CO}_{3}{ }^{2-}\right\}$ the ion activity product of the solution (Nielsen, 1964, 1984; Nancollas and Reddy, 1971; Nielsen and Toft, 1984; Teng et al., 2000; many others). Besides $\Omega$, the aqueous composition may also affect the growth rate of carbonate minerals via the solution metal cation to $\mathrm{CO}_{3}{ }^{2-}$ concentration ratio (Zuddas and Mucci, 1994; Sternbeck, 1997). However, in published studies, the degree of supersaturation with respect to calcite and the concentration ratio of dissolved $\mathrm{Ca}^{2+}$ to $\mathrm{CO}_{3}^{2-}$ ions generally vary together (Lorens, 1981; Christoffersen and Christoffersen, 1990; Tesoriero and Pankow, 1996; van der Weijden et al., 1997; Lemarchand et al., 2004). This hinders 
an evaluation of distinct effects of the solution stoichiometry and ion activity product on calcite growth kinetics.

In this study, growth rates of single calcite crystals were measured as a function of solution stoichiometry, at fixed $\mathrm{pH}$ and fixed degree of supersaturation. To create $\mathrm{Ca}^{2+}$ to $\mathrm{CO}_{3}{ }^{2-}$ concentration ratios both larger and smaller than one, the experiments were conducted at a fairly high $\mathrm{pH}$ (10.2). Furthermore, the incorporation of trace amounts of $\mathrm{Sr}$ during calcite precipitation was monitored, in order to determine how the solution to solid partitioning of this cation depends on the growth kinetics and $\mathrm{Ca} / \mathrm{CO}_{3}$ solution composition. Strontium was selected because of the low solubility of $\mathrm{SrCO}_{3}$ in aqueous solution, and because the ionic radius of $\mathrm{Sr}^{2+}$ is close to that of $\mathrm{Ca}^{2+}$, therefore minimizing the effects of the trace metal cation on the growth rate of calcite.

\section{THEORETICAL BACKGROUND}

\subsection{Crystal growth kinetics and solution stoichiometry}

Kossel (1927) and Stranski (1928) developed a crystal growth model wherein a growth unit $(\mathrm{GU})$ can attach to six distinct surface sites (Fig. 1A). These sites differ in their potential energy with respect to attachment of a GU. Because the attachment to a kink site (KiS) does not alter the number of bonds available at the mineral surface, it represents the energetically most favourable site for the incorporation of GU into the crystal lattice. Hence, a possible mechanism for growth of a crystal from a liquid or vapour phase involves the following succession of steps: (i) adsorption of a GU onto the crystal surface, (ii) diffusion to a step, and (iii) incorporation into a kink site.
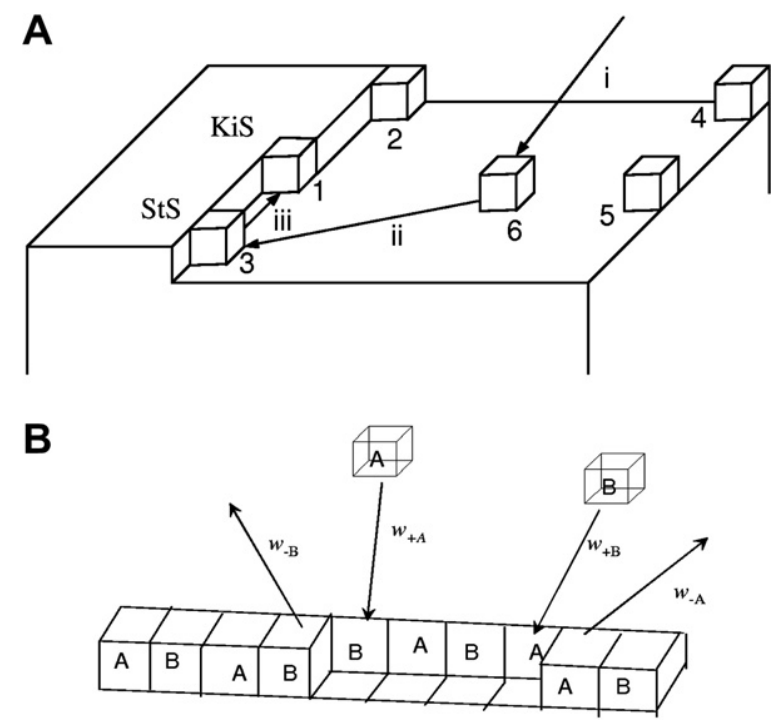

Fig. 1. (A) Surface sites on a cubic crystal ("Kossel crystal", modified after Sawada, 1998), and successive steps in crystal growth (i, ii, iii). Positions $1-6$ are characterized by different attachment/detachment energies (KiS, kink site; StS, step site). (B) When growth requires incorporation of alternating ions, A and B, the attachment $\left(w_{+}\right)$and detachment $\left(w_{-}\right)$frequencies of both ions influence the growth rate.
Depending on the degree of supersaturation, $\Omega$, different growth modes may dominate, e.g., spiral growth, twodimensional nucleation, which itself can be subdivided in different modes, e.g., layer-by-layer and multilayer (Markov, 2003). All these modes have in common that the growth rate can be described in terms of the attachment and detachment frequencies of GUs to and from all possible surface sites. (Note that the latter also applies to mineral dissolution, Lasaga and Lüttge, 2005.) The resulting rate equations are typically simplified and only account for the dominant surface lattice site(s), in general the kink sites (KiS, Fig. 1A).

In the original model of Kossel and Stranski, the socalled Kossel crystal consists of a cubic lattice composed of a single chemical species, the GU (Zhang and Nancollas, 1990). Strictly speaking, the model of Kossel and Stranski applies to elemental or molecular crystals, and $\Omega$ is equal to the ratio of the activity of the $\mathrm{GU}$ in the fluid phase and the corresponding equilibrium value. For the precipitation from aqueous solution of a mineral such as calcite, crystal growth involves the alternating incorporation of cations and anions $\left(\mathrm{Ca}^{2+}\right.$ and $\left.\mathrm{CO}_{3}{ }^{2-}\right)$ into the lattice (Fig. 1B). In this case, the growth rate also depends on the relative abundances of the cations and anions in solution, in addition to $\Omega$. Several researchers have extended the original Kossel crystal growth model to describe the precipitation of multicomponent non-Kossel crystals from aqueous solution (Zhang and Nancollas, 1998; Chernov, 2001; Chernov et al., 2006).

One of the few studies in which the predictions of nonKossel crystal growth theory are directly compared to experimental data is that of Chernov et al. (2006). These authors measured the effect of solution stoichiometry on the step propagation velocities of $\mathrm{CaC}_{2} \mathrm{O}_{4} \cdot \mathrm{H}_{2} \mathrm{O}$ and $\mathrm{MgC}_{2} \mathrm{O}_{4} \cdot 2 \mathrm{H}_{2} \mathrm{O}$ by means of atomic force microscopy (AFM). They observed that, at constant degree of supersaturation, the step rates measured on various crystal faces reached their maximum values when the concentration ratio of cation to anion in solution, $r$, equalled one. Furthermore, the rates decreased symmetrically away from $r=1$, that is, $v_{k}(r)=v_{k}(1 / r)$. Both observations are in agreement with non-Kossel crystal growth theory, if the frequency factors describing attachment of the cation and anion are the same. As noted by Chernov and co-workers, "this symmetry exists in spite of fact that the $\mathrm{Ca}^{2+}$ and $\mathrm{Mg}^{2+}$ ions on the one hand and the $\mathrm{C}_{2} \mathrm{O}_{4}{ }^{2-}$ on the other have different size, shape and spatial symmetry".

\subsection{Trace element partitioning}

The distribution of a trace metal, for example $\mathrm{Sr}$, between calcite and the aqueous phase from which the mineral forms can be described by a partition coefficient $D_{\mathrm{Tr}}$, defined as,

$D_{\operatorname{Tr}}=\frac{[\operatorname{Tr}]_{\mathrm{s}} /[\operatorname{Tr}]_{1}}{[M]_{\mathrm{s}} /[M]_{1}}$

where $[\mathrm{Tr}]$ and $[M]$ are the molar concentrations of the trace (strontium) and major (calcium) element in the solid (s) and liquid (l) phase, respectively. The partition coefficient 
represents a phenomenological coefficient (Morse and Bender, 1990), and is distinct from the thermodynamic distribution constant, $K_{D_{\mathrm{Tr}}}$. The latter is defined in terms of the activities of the trace and major ions in both phases at thermodynamic equilibrium (McIntire, 1963).

Rimstidt et al. (1998) estimated the values of $K_{D_{\mathrm{Tr}}}$ for incorporation into calcite of many elements by fitting a large dataset from the literature. Their work, and many other experimental investigations (Kitano et al., 1971; Kitano and Oomori, 1971; Lorens, 1981; Mucci and Morse, 1983; Pingitore and Eastman, 1984; Mucci, 1986; Tesoriero and Pankow, 1996; Temmam et al., 2000) have shown that the difference between the thermodynamic distribution constant, $K_{D_{\mathrm{Tr}}}$, and the empirical partition coefficient, $D_{\mathrm{Tr}}$, reflects kinetic effects, in particular the growth rate of the host crystal. For trace elements with $K_{D_{\mathrm{Tr}}}>1$, measured $D_{\operatorname{Tr}}$ values are generally lower than the equilibrium value, and vice versa for $K_{D_{\mathrm{Tr}}}<1$. When the growth rate tends to zero ("growth at equilibrium"), $D_{\mathrm{Tr}}$ approaches $K_{D_{\mathrm{Tr}}}$.

\section{MATERIALS AND METHODS}

Growth rates were determined on calcite single crystals of known mass, each placed at the bottom of a separate flow-through reactor. The solutions flown through the reactors were characterized by two different supersaturations and variable $\left[\mathrm{Ca}^{2+}\right]$ to $\left[\mathrm{CO}_{3}{ }^{2-}\right]$ ratios, but constant $\mathrm{pH}$. At the end of an experiment, each crystal was weighted to determine the mass of calcite grown during the experiment. Measurement of $\mathrm{Sr}$ incorporation was carried out by laser ablation inductively coupled plasma mass spectrometry (LA-ICP-MS).

\subsection{Crystal growth experiments}

\subsubsection{Seed material}

Calcite seed crystals were produced from an Iceland spar. The latter had a size of approximately $5 \mathrm{~cm} \times 5 \mathrm{~cm} \times 2 \mathrm{~cm}$. It was cleaved manually using a small flat chisel to produce crystals of approximately $1-1.5 \mathrm{~mm}^{3}$
(Fig. 2A). Crystals showing little damage (as shown in Fig. 2A) were handpicked under a binocular and cleaned in an ultrasonic bath to remove loose particles. The soaking solution was a calcite-saturated aqueous solution prepared from reverse osmosis water (conductivity $<0.067 \mu \mathrm{S}$ ) and Suprapure $^{\circledR}\left(\right.$ Merck $\left.^{\circledR}\right)$ calcite powder. The crystals were then stored for 2 months in the saturated Suprapure ${ }^{\circledR}$ calcite solution, to provide equilibrated surfaces for growth. Prior to the experiments, the crystals were washed with ethanol to avoid precipitation from water droplets during drying. The crystals were then dried in an oven at $40{ }^{\circ} \mathrm{C}$ for $1 \mathrm{~h}$, weighted on a Mettler Toledo ${ }^{\circledR}$ UMX2 micro-balance, with a resolution of $0.1 \mu \mathrm{g}$, and transferred into the flow-through reactors. Each reactor contained a single crystal.

\subsubsection{Crystal growth experiments}

Reactors with an inner diameter of $5 \mathrm{~mm}$ and a depth of $15 \mathrm{~mm}$ were built out of Teflon ${ }^{\circledR}$ (Fig. 3). The reactor inlet was connected to a $50 \mathrm{~mm}$ long Tygon $^{\circledR}$ tubing (ID $=1.6 \mathrm{~mm}, \quad \mathrm{OD}=4.8 \mathrm{~mm})$, which collected solutions coming from two separate reservoirs via a Y-connector. One solution contained the $\mathrm{Ca}^{2+}$ ions, the other the $\mathrm{CO}_{3}^{2-}$ ions. Tedlar ${ }^{\circledR}$ bags where used as solution reservoirs, to avoid the formation of a headspace while the solutions were pumped out of the bags. Flow was adjusted to $10 \mu 1 \mathrm{~min}^{-1}$ with a 16 channel Watson Marlow ${ }^{\circledR}$ (S205) peristaltic pump, and found to remain constant from the measurement of outflow volumes. Tubing wall thickness and bag material were chosen to minimize gas exchange with the atmosphere $\left(\right.$ Tedlar $^{\circledR}$ bags were originally designed for gas sampling). For each reactor inflow solution composition, four replicates were run by connecting four reactors to one set of bags. All experiments were performed in a thermostated laboratory at $20 \pm 0.2{ }^{\circ} \mathrm{C}$.

The $\mathrm{Ca}^{2+}$ and $\mathrm{CO}_{3}{ }^{2-}$ solutions were prepared by dissolving Merck ${ }^{\circledR}$ Suprapure ${ }^{\circledR} \mathrm{CaCl}_{2} \cdot 4 \mathrm{H}_{2} \mathrm{O}$ and $\mathrm{K}_{2} \mathrm{CO}_{3}$ in filtered $(0.2 \mu \mathrm{m}$ pore size) reverse osmosis water (conductivity $<0.067 \mu \mathrm{S}$ ), with $0.1 \mathrm{M} \mathrm{NaCl}$ as background electrolyte. Strontium was added to the $\mathrm{Ca}^{2+}$ solution as $\mathrm{SrCl}_{2}$. The $\mathrm{Ca}: \mathrm{Sr}$ ratios were on the order of 100:1. The equilibrium
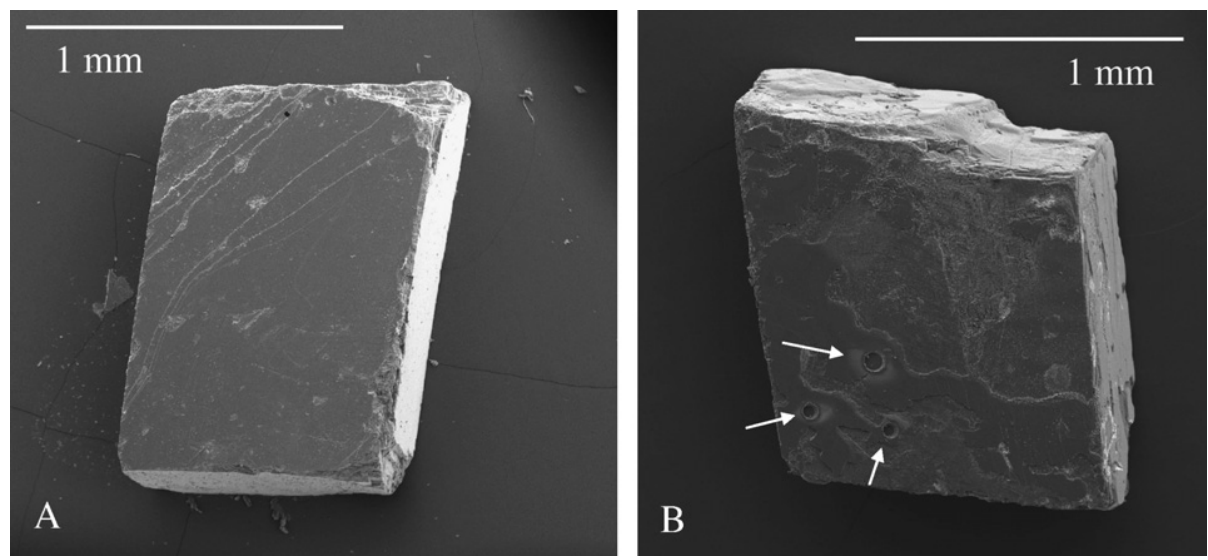

Fig. 2. Scanning electron micrograph A shows a typical calcite crystal used as seed material in the flow-through reactor experiments. Micrograph B shows a calcite seed with an overgrowth collected at the end of a precipitation experiment. In the lower left corner three ablation holes are visible, produced during the LA-ICP-MS analysis (arrows). 


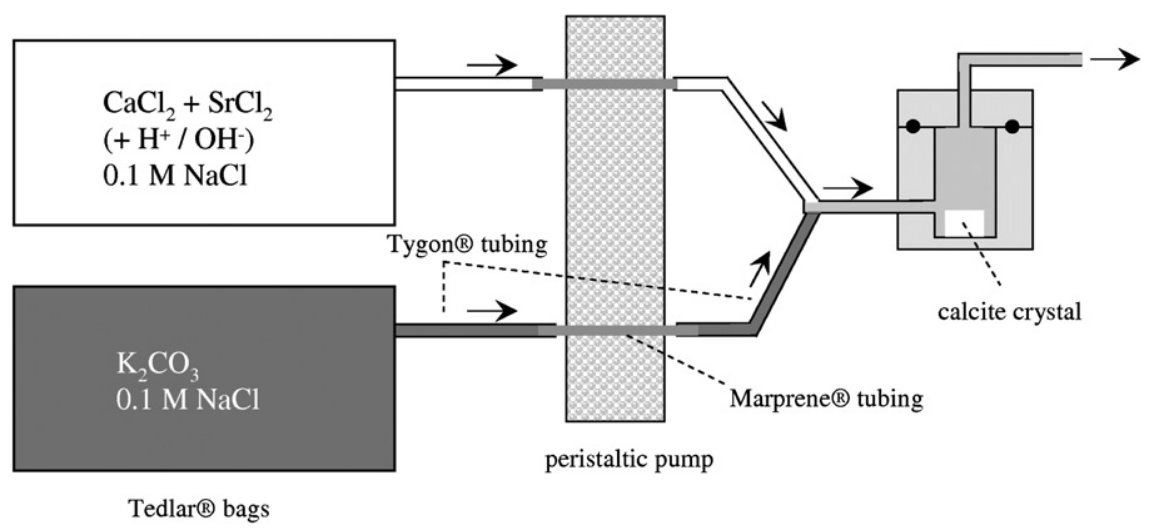

Fig. 3. Experimental setup. Flow was maintained by a peristaltic pump, and $\mathrm{Ca}^{2+}$ and $\mathrm{CO}_{3}{ }^{2-}$ solutions in Tedlar ${ }^{\circledR}$ bags were mixed prior to entering the flow-through reactor. The latter contains a single calcite seed crystal, placed at the bottom of the reactor.

chemical speciation of the inflow solution obtained after mixing of the $\mathrm{Ca}^{2+}$ and $\mathrm{CO}_{3}{ }^{2-}$ solutions was calculated using Visual Minteq V. 2.40 (Gustafsson, 2004). The calculations showed that all inflow solutions, except one (reac001), were undersaturated with respect to $\mathrm{SrCO}_{3}$.

$\mathrm{A} \mathrm{pH}$ of around 10 was selected for the inflow solutions. At this $\mathrm{pH}, \mathrm{CO}_{3}{ }^{2-}$ is a major dissolved carbon species, which facilitated the preparation of stoichiometric $\left[\mathrm{Ca}^{2+}\right]$ to $\left[\mathrm{CO}_{3}{ }^{2-}\right]$ ratios ranging from less than one to greater than one, while maintaining constant ionic strength. In addition, to produce a $\mathrm{pH}$ around 10 , only small additions of acid to the $\mathrm{Ca}^{2+}$ solution were required, thereby avoiding corrosion of the stainless steel $\mathrm{Y}$-connector used for mixing the $\mathrm{Ca}^{2+}$ and $\mathrm{CO}_{3}{ }^{2-}$ solutions. Table 1 lists the compositions of the 12 different reactor inflow solutions. Based on the measured calcite growth rates, less than $1 \%$ of the $\mathrm{Ca}^{2+}$ and $\mathrm{CO}_{3}{ }^{2-}$ ions supplied via the inflow precipitated in the reactors. Therefore, the solution composition inside the reactor was assumed to be equal to that of the inflow solution.

Dissolved $\mathrm{Ca}^{2+}$ and $\mathrm{Sr}^{2+}$ concentrations were measured in four replicates by inductively coupled plasma-optical emission spectroscopy (ICP-OES). Dissolved inorganic car- bon (DIC) was measured in duplicates on a Shimadzu ${ }^{\circledR}$ TOC550 analyzer. The $\mathrm{pH}$ of the inflow solution was checked before connecting the tubing to the reactor. The measured $\mathrm{pH}$ values matched the expected value of $10.15 \pm 0.1$ (Table 1), confirming the $1: 1$ mixing ratio of the $\mathrm{Ca}^{2+}$ and $\mathrm{CO}_{3}{ }^{2-}$ solutions. The $\mathrm{pH}$ of the outflow was also periodically measured using a Metrohm ${ }^{\circledR} 713$ $\mathrm{pH}$ meter with an Metrohm ${ }^{\circledR}$ Unitrode $^{\circledR} \mathrm{pH}$ electrode (calibrated against NISTtraceable buffer solutions) and found to remain stable and equal to the inflow $\mathrm{pH}$.

\subsubsection{Determination of calcite growth rates}

At the end of an experiment, the crystal was removed from the reactor, washed with ethanol and dried for $1 \mathrm{~h}$ in the oven at $40^{\circ} \mathrm{C}$, before weighing. The transfer to and from the reactor and balance was done by means of a Teflon ${ }^{\circledR}$ beaker with an inner diameter of $5 \mathrm{~mm}$. No tools were used to pick up the crystal in order to avoid any breakage. Growth rates $(R)$ were calculated as

$R=\left(\frac{m t_{1}-m t_{0}}{m t_{0}}\right) 100 / t_{1}$

Table 1

Inflow solution compositions for the precipitation experiments using the flow-through reactors

\begin{tabular}{|c|c|c|c|c|c|c|c|}
\hline Experiment & $\begin{array}{l}{[\mathrm{Ca}]} \\
\mathrm{mmol} \mathrm{L}{ }^{-1}(\mathrm{ICP}-\mathrm{OES})\end{array}$ & $\begin{array}{l}{[\mathrm{Sr}]} \\
\mu \mathrm{mol} \mathrm{L}{ }^{-1}(\mathrm{ICP}-\mathrm{OES})\end{array}$ & $\begin{array}{l}\mathrm{pH} \\
(\text { mean) }\end{array}$ & $\begin{array}{l}{\left[\mathrm{CO}_{3}^{2-}\right]} \\
\mathrm{mmol} \mathrm{L}^{-1} \text { (calc.) }\end{array}$ & $\begin{array}{l}{\left[\mathrm{Ca}^{2+}\right]} \\
\text { mmol L } \\
-1 \text { (calc.) }\end{array}$ & $\begin{array}{l}1 / r \\
\text { (calc.) }\end{array}$ & $\begin{array}{l}\Omega \\
\text { (calc.) }\end{array}$ \\
\hline reac $004 n$ & $15.6 \pm 0.4$ & n.d. & $10.2 \pm 0.1$ & 0.037 & 14.180 & 0.003 & 19 \\
\hline reac005 & $1.77 \pm 0.06$ & $21.8+0.1$ & $10.2 \pm 0.1$ & 0.211 & 1.559 & 0.14 & 14 \\
\hline reac001 & $0.88 \pm 0.02$ & $57.9 \pm 0.2$ & $10.2 \pm 0.1$ & 0.444 & 0.737 & 0.6 & 14 \\
\hline reac007 & $0.38 \pm 0.02$ & $3.9 \pm 0.2$ & $10.1 \pm 0.1$ & 1.501 & 0.266 & 5.6 & 16 \\
\hline reac006n & $0.20 \pm 0.03$ & $1.9 \pm 0.1$ & $10.2 \pm 0.1$ & 4.563 & 0.088 & 52 & 17 \\
\hline reac $002 a$ & $0.160 \pm 0.003$ & n.d. & $10.2 \pm 0.1$ & 4.432 & 0.078 & 57 & 14 \\
\hline reac008 & $2.01 \pm 0.02$ & $20.2 \pm 0.2$ & $10.2 \pm 0.1$ & 0.073 & 1.895 & 0.04 & 6 \\
\hline reac003 & $0.58 \pm 0.02$ & $7.80 \pm 0.06$ & $10.1 \pm 0.1$ & 0.222 & 0.524 & 0.42 & 5 \\
\hline reac $003 n$ & $0.58 \pm 0.02$ & $7.78 \pm 0.07$ & $10.1 \pm 0.1$ & 0.235 & 0.424 & 0.45 & 5 \\
\hline reac009 & $0.15 \pm 0.02$ & n.d. & $10.2 \pm 0.1$ & 0.936 & 0.115 & 8.1 & 5 \\
\hline reac002bn & $0.086 \pm 0.001$ & n.d. & $10.2 \pm 0.1$ & 2.185 & 0.054 & 40 & 5 \\
\hline reac $002 b$ & $0.086 \pm 0.002$ & n.d. & $10.2 \pm 0.1$ & 2.366 & 0.052 & 45 & 5 \\
\hline
\end{tabular}

The table lists the measured (ICP-OES) total concentrations of $\mathrm{Ca}$ and $\mathrm{Sr}$, as well as the (free) ion concentrations, $\left[\mathrm{Ca}^{2+}\right]$ and $\left.^{2} \mathrm{CO}_{3}{ }^{2-}\right]$, calculated using Visual Minteq. Also given are the reciprocals of the stoichiometric solution ratios, $1 / r$, and the degrees of supersaturation with respect to calcite, $\Omega$. 


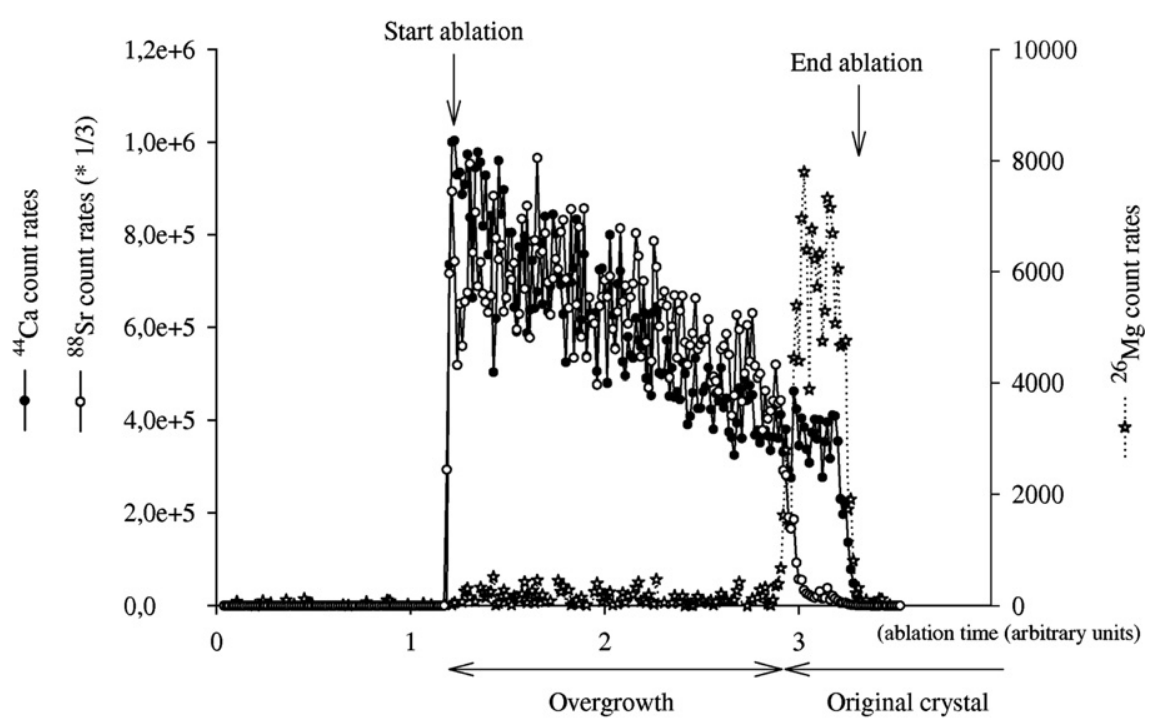

Fig. 4. Typical ablation profile through a calcite crystal collected after a growth experiment with Sr-containing inflow solution. The Mg and $\mathrm{Sr}$ counts clearly distinguish the original seed crystal from the newly formed calcium carbonate layer. Both $\mathrm{Ca}$ and $\mathrm{Sr}$ counts decrease during the ablation as the bottom of the ablation crater steadily becomes deeper. The ratio of Sr to Ca, however, remains constant, indicating a homogeneous composition of the calcium carbonate overgrowth. $\mathrm{Mg}$ is present at concentrations of about $600 \mathrm{ppm}$ in the original crystal, but is absent from the reaction fluids.

where $m t_{0}$ and $m t_{1}$ are the initial and final crystal masses, respectively, and $t_{1}$ the duration of the growth experiment. Rates were normalized to the geometric surface area of the crystals' exposed surfaces (one (104) face +4 edges). The geometric surface area of each crystal seed was determined on the basis of measurements carried out under an optical microscope.

\subsection{Sr concentrations in calcite overgrowths}

After the growth experiments, crystals were ablated using a deep ultra-violet-wavelength laser (193 nm, Lambda Physik excimer laser with GeoLas 200Q optics), which is essential for carbonate minerals, as they do not absorb laser radiation well at higher wavelengths (Jackson et al., 1992). Ablation was performed in a helium atmosphere at a pulse repetition rate of $6 \mathrm{~Hz}$ with an energy density at the sample surface of $2 \mathrm{~J} \mathrm{~cm}^{-2}$. The aperture was set to make craters of $80 \mu \mathrm{m}$ in diameter (too large to resolve sector zoning). A relatively low energy was used to increase the analysis time in the $\mathrm{CaCO}_{3}$ overgrowth, before the bottom of the ablation crater reached the original crystal. The ablated material was analyzed with respect to time (and hence depth) using a quadrupole ICP-MS instrument (Micromass Platform ICP). Calibration was performed against NIST (US National Institute of Standards and Technology) SRM 610 glass using the concentration data of Pearce et al. (1997), with Ca as an internal standard at a constant concentration of $40 \mathrm{wt} \%$. Inter-elemental fractionation (Mank and Mason, 1999) was insignificant at the low depth/diameter ratio of the ablation craters produced in this study (typical ablation craters can be seen in Fig. 2B).

A collision and reaction cell described in detail by Mason and Kraan (2002) was used to reduce spectral interfer- ences on the minor isotopes of $\mathrm{Ca}\left({ }^{42} \mathrm{Ca},{ }^{43} \mathrm{Ca}\right.$ and $\left.{ }^{44} \mathrm{Ca}\right)$. Multiple isotopes $\left({ }^{24} \mathrm{Mg},{ }^{26} \mathrm{Mg},{ }^{27} \mathrm{Al},{ }^{55} \mathrm{Mn}\right.$ and $\left.{ }^{88} \mathrm{Sr}\right)$ were used where possible to confirm accurate concentration determinations. Relative analytical error, based on repeated analyses of an independently calibrated in-house carbonate standard was $\pm 4 \%$ for $\mathrm{Sr}$. The $\mathrm{Mg}$ and $\mathrm{Mn}$ counts were used to identify the transition between the overgrowth and the original crystal, as both elements were virtually absent in the overgrowth, but present at constant levels ( $\sim 700$ ppm Mg, $\sim 100$ ppm Mn) in the seed crystals. A typical ablation spectrum is shown in Fig. 4.

\section{RESULTS AND DISCUSSION}

\subsection{Growth rates and solution stoichiometry}

The calcite crystal growth rates determined with the single-crystal method vary by a factor of about 15 (Table 2). Although the growth kinetics depend on both the degree of supersaturation and the solution stoichiometry, most of the variability of the measured rates is due to changes of the concentration ratio $r=\left[\mathrm{Ca}^{2+}\right] /\left[\mathrm{CO}_{3}{ }^{2-}\right]$ (Fig. 5). At the experimental $\mathrm{pH}(10.15 \pm 0.1)$, and for both degrees of supersaturation $(\Omega=5 \pm 1,16 \pm 2)$, the rates decrease symmetrically away from $r=1$. To our knowledge, this is the first time a growth rate optimum for a stoichiometric solution composition $(r=1)$ is reported for calcite.

A number of authors has recognized that the growth rate of calcite and other divalent metal carbonates should depend on the relative abundances of metal and carbonate ions (Zuddas and Mucci, 1994; Sternbeck, 1997; Lebron and Suarez, 1998). However, the effects of supersaturation and solution stoichiometry have rarely been assessed separately, because in most growth studies changes in $r$ coincide 
Table 2

Initial and final crystal weights, plus the total durations of the growth experiments

\begin{tabular}{|c|c|c|c|c|}
\hline Experiment & Crystal & $m t_{0}(\mu \mathrm{g})$ & $m t_{1}(\mu \mathrm{g})$ & Duration $\left(t_{1}\right)(\mathrm{h})$ \\
\hline \multirow{4}{*}{ reac004n } & B05 & 5222 & 5255 & 266 \\
\hline & B20 & 5102 & 5141 & 266 \\
\hline & B27 & 5568 & 5622 & 266 \\
\hline & B28 & 5133 & 5192 & 266 \\
\hline \multirow[t]{4}{*}{ reac005 } & A14 & 2968 & 3338 & 821 \\
\hline & A15 & 2060 & 2400 & 821 \\
\hline & A18 & 2994 & 3362 & 821 \\
\hline & A21 & 2496 & 2925 & 819 \\
\hline \multirow[t]{4}{*}{ reac001 } & 003 & 3511 & 4456 & 723 \\
\hline & 004 & 3803 & 4813 & 601 \\
\hline & 010 & 3157 & 4202 & 771 \\
\hline & 015 & 3662 & 4445 & 771 \\
\hline \multirow[t]{4}{*}{ reac007 } & $\mathrm{C} 01$ & 3612 & 3992 & 612 \\
\hline & $\mathrm{C} 12$ & 3542 & 3975 & 612 \\
\hline & $\mathrm{C} 13$ & 3524 & 3936 & 612 \\
\hline & $\mathrm{C} 21$ & 3802 & 4142 & 612 \\
\hline \multirow[t]{4}{*}{ reac006n } & $\mathrm{B} 15$ & 4643 & 5156 & 1266 \\
\hline & $\mathrm{B} 18$ & 4841 & 5050 & 1266 \\
\hline & B26 & 4611 & 4802 & 1266 \\
\hline & B32 & 4836 & 5036 & 1266 \\
\hline \multirow[t]{4}{*}{ reac002a } & A08 & 2919 & 2976 & 841 \\
\hline & A13 & 2955 & 3014 & 841 \\
\hline & A20 & 2429 & 2498 & 841 \\
\hline & A24 & 3347 & 3412 & 841 \\
\hline \multirow[t]{3}{*}{ reac008 } & $\mathrm{C} 03$ & 2923 & 3014 & 1045 \\
\hline & $\mathrm{C} 06$ & 3001 & 3072 & 1045 \\
\hline & $\mathrm{C} 09$ & 2854 & 2937 & 1045 \\
\hline \multirow[t]{4}{*}{ reac003 } & 007 & 1862 & 2838 & 1969 \\
\hline & 014 & 4047 & 5432 & 1969 \\
\hline & 017 & 3550 & 4750 & 1969 \\
\hline & 020 & 2416 & 3539 & 1961 \\
\hline \multirow[t]{4}{*}{ reac $003 n$} & $\mathrm{~B} 10$ & 2684 & 3301 & 1079 \\
\hline & B29 & 2967 & 3738 & 1079 \\
\hline & B30 & 2913 & 3980 & 1079 \\
\hline & B38 & 2909 & 3470 & 1079 \\
\hline \multirow[t]{3}{*}{ reac009 } & $\mathrm{C} 11$ & 3012 & 3527 & 1736 \\
\hline & $\mathrm{C} 17$ & 3235 & 3789 & 1736 \\
\hline & $\mathrm{C} 08$ & 3423 & 3905 & 1736 \\
\hline \multirow[t]{4}{*}{ reac002bn } & B02 & 3949 & 4072 & 1079 \\
\hline & B11 & 4069 & 4209 & 1079 \\
\hline & B29 & 3521 & 3632 & 1079 \\
\hline & B24 & 3583 & 3672 & 1079 \\
\hline \multirow[t]{4}{*}{ reac $002 b$} & 011 & 2769 & 2861 & 1369 \\
\hline & 012 & 3433 & 3549 & 1369 \\
\hline & 016 & 3196 & 3317 & 1369 \\
\hline & 018 & 3594 & 3710 & 1369 \\
\hline
\end{tabular}

with changes in $\Omega$ during the experiments (Christoffersen and Christoffersen, 1990; van der Weijden et al., 1997; Nilsson and Sternbeck, 1999). In addition, experiments are generally conducted under conditions where $\left[\mathrm{Ca}^{2+}\right] \gg\left[\mathrm{CO}_{3}{ }^{2-}\right]$, thereby excluding the range of $r$ over which the rate optimum is observed.

Winter and Burton (1992) found that the precipitation rate of calcite increased by more than one order of magnitude when $r$ decreased from $2 \times 10^{5}$ to 1 , while $\Omega$ was kept constant (reported in Zuddas and Mucci, 1994). This result implies that a potential rate optimum must occur at $r \leqslant 1$, which is consistent with our data. However, to fully characterize the effect of solution stoichiometry, growth kinetics must also be measured in solutions where $\left[\mathrm{Ca}^{2+}\right]<\left[\mathrm{CO}_{3}{ }^{2-}\right]$. The most straightforward approach is to work at high $\mathrm{pH}$, as done in the present study, because $\mathrm{CO}_{3}{ }^{2-}$ accounts for a significant fraction of the dissolved inorganic carbon.

The symmetric rate dependence on solution stoichiometry in Fig. 5 is similar to those observed by Chernov et al. (2006) for step propagation rates on calcium oxalate monohydrate $\left(\mathrm{CaC}_{2} \mathrm{O}_{4} \cdot \mathrm{H}_{2} \mathrm{O}\right)$ and magnesium oxalate dihydrate $\left(\mathrm{MgC}_{2} \mathrm{O}_{4} \cdot 2 \mathrm{H}_{2} \mathrm{O}\right)$. For instance, at a constant supersaturation of $\Omega=2.6$, the propagation of [001] steps on the (100) face of $\mathrm{CaC}_{2} \mathrm{O}_{4} \cdot \mathrm{H}_{2} \mathrm{O}$ drops by a factor of about 6 when the solution ratio, $r=\left[\mathrm{Ca}^{2+}\right] /\left[\mathrm{C}_{2} \mathrm{O}_{4}{ }^{2-}\right]$, increases from 1 to 10 , or decreases from 1 to 0.1 . At $r$ values greater than 10 , or smaller than 0.1 , little further change in the step rate is observed. Chernov and coworkers interpreted the observed effect of $r$ on the growth kinetics of $\mathrm{CaC}_{2} \mathrm{O}_{4} \cdot \mathrm{H}_{2} \mathrm{O}$ and $\mathrm{MgC}_{2} \mathrm{O}_{4} \cdot 2 \mathrm{H}_{2} \mathrm{O}$ within the framework of the non-Kossel crystal growth theory for binary salts (Zhang and Nancollas, 1998). According to the theory, the attachment frequencies of the cation and anion to kink sites at the mineral surface are proportional to their respective concentrations in solution. A symmetric rate distribution is predicted when the proportionality constants, or frequency factors, are the same for the cation and anion.

Identical frequency factors for the incorporation of cation and anion into kink sites are rather unexpected, as also remarked by Chernov et al. (2006). The slower dehydration of the cation is often assumed to be rate-limiting for surface reaction-controlled growth of salt-type minerals (Nielsen, 1984). However, this would result in a rate optimum at $r>1$, which is not the case. Possibly, the net negative surface charge of calcite at the high $\mathrm{pH}$ of our study $\left(\mathrm{pH}_{\mathrm{ZPC}} \approx 8\right.$, Van Cappellen et al., 1993) facilitates the incorporation of $\mathrm{Ca}^{2+}$ ions into the lattice, and results in comparable frequency factors for the attachment of $\mathrm{Ca}^{2+}$ and $\mathrm{CO}_{3}{ }^{2-}$ ions. A logical extension of the work presented here would therefore be to determine the dependence of the calcite growth rate on $r$ over a range of $\mathrm{pH}$ and, therefore, a range of surface charge and surface speciation.

Most natural waters are characterized by $\left[\mathrm{CO}_{3}{ }^{2-}\right]$ to $\left[\mathrm{Ca}^{2+}\right]$ ratios much smaller than one. For example, $r$ values for surface ocean waters are on the order of 100 (Zeebe and Westbroek, 2003), while in freshwater and marine sediment pore waters $r$ typically varies between 50 and 2000 (Cai et al., 2000; Mueller et al., 2003; Jahnke \& Jahnke, 2004). Hence, the solution stoichiometries of these waters fall mostly outside the range of $r$ where a strong effect on calcite growth kinetics is expected (Fig. 5). Changes in solution composition then mainly affect the growth rate via the degree of supersaturation. This, however, may no longer be the case for biologically mediated calcite precipitation. Organisms such as marine calcifying algae actively regulate $\mathrm{Ca}^{2+}$ transport from the surrounding seawater to the site of calcification through cell physiological processes (Langer et al., 2006). In the highly controlled cell environment, $r$ may differ significantly from the value in the bulk medium. Solution stoichiometry may therefore provide calcifying 


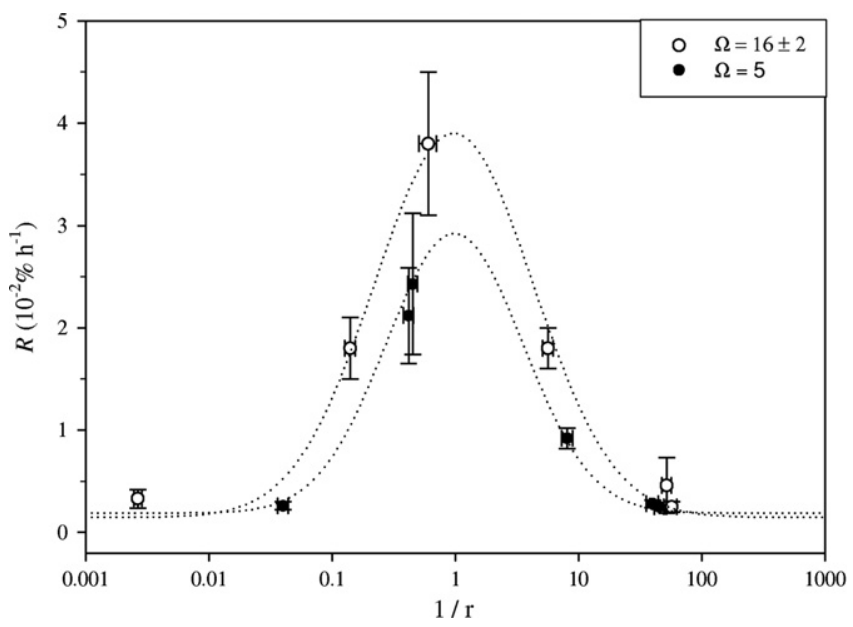

Fig. 5. Growth rate versus the inverse of the solution $\left[\mathrm{Ca}^{2+}\right] /\left[\mathrm{CO}_{3}{ }^{2-}\right]$ ratio, $r$, for two different degrees of supersaturation with respect to calcite. (Error bars denote standard deviations. The dotted lines are only a guide to the eye, not theoretical curves. They emphasize the symmetrical distribution of the growth rates with respect to $r=1$.)

organisms with an additional means to control the mineralization process.

\subsection{Sr partition coefficients}

The LA-ICP-MS ablation spectra of the calcite overgrowths show the expected high ${ }^{88} \mathrm{Sr}$ and low ${ }^{26} \mathrm{Mg}$ signals (Fig. 4). Average Sr partitioning coefficients derived from the ${ }^{88} \mathrm{Sr}$ and ${ }^{44} \mathrm{Ca}$ counts and the solution composition are listed in Table 3. The distribution coefficients increase with the calcite growth rate (Fig. 6). As for the growth rate itself, most of the observed variability in $D_{\mathrm{Sr}}$ reflects differences in the $\left[\mathrm{Ca}^{2+}\right] /\left[\mathrm{CO}_{3}{ }^{2-}\right]$ solution ratio among the experiments, rather than differences in the degree of supersaturation.

A positive correlation of $D_{\mathrm{Sr}}$ and the growth rate of calcite has also been reported by Lorens (1981) and Tesoriero and Pankow (1996). These authors, however, used calcite powder as seed material instead of single crystals. Bulk precipitation rates (e.g., in units of mass \% per time) in the experiments of Tesoriero and Pankov were up to two orders of magnitude faster than measured here, reflecting the much higher mineral surface areas of the minerals used there. However, the two studies yield trends between $D_{\mathrm{Sr}}$ and the growth rate that are in reasonable agreement, when the growth rates are normalized to the geometric surface areas of the two different calcite seed materials (Fig. 7).

In both studies, the lowest values of $D_{\mathrm{Sr}}$ are on the order of 0.02 , which corresponds to the equilibrium value, $K_{D_{\mathrm{Sr}}}$ (Rimstidt et al., 1998). According to Tesoriero and Pankov, their highest incorporation of $\operatorname{Sr}\left(D_{\mathrm{Sr}}=0.14\right)$ is partially due to formation of discrete inclusions of $\mathrm{SrCO}_{3}$. Similarly, our highest value of $D_{\mathrm{Sr}}(0.21)$ corresponds to the experiment in which the solution was supersaturated with respect to $\mathrm{SrCO}_{3}(\Omega=3)$. If the two highest $D_{\mathrm{Sr}}$ values are excluded, the combined data set in Fig. 7 might imply a saturation plateau for $\mathrm{Sr}$ incorporation around $D_{\mathrm{Sr}} \approx 0.12$. A maximum $D_{\mathrm{Sr}}$ value around 0.12 was proposed by Stoll et al. (2002), based on the surface enrichment model for trace elements of Watson (1996) and Watson and Liang (1995).

Table 3

Crystal growth rates and $\mathrm{Sr}$ partition coefficients

\begin{tabular}{|c|c|c|c|c|c|}
\hline Experiment & $R 10^{-2}\left(10^{-2_{0}} \% \mathrm{~h}^{-1}\right)$ & $R \mathrm{nmol} \mathrm{cm}{ }^{-2} \min ^{-1}$ & $\mathrm{Sr} / \mathrm{Ca} \mathrm{mmol} \mathrm{mol}{ }^{-1}$ & $n_{\mathrm{m}} / n_{\mathrm{c}}$ & $D_{\mathrm{Sr}}$ \\
\hline reac $004 n$ & $0.33 \pm 0.09$ & $5.8 \pm 1.5$ & n.d. & - & - \\
\hline reac005 & $1.8 \pm 0.3$ & $51.7 \pm 14.6$ & $0.7 \pm 0.2$ & $2 / 1$ & $0.07 \pm 0.02$ \\
\hline reac001 & $3.8 \pm 0.7$ & $88.7 \pm 19.2$ & $14 \pm 2$ & $8 / 2$ & $0.21 \pm 0.03$ \\
\hline reac007 & $1.8 \pm 0.2$ & $40.6 \pm 6.3$ & $1.2 \pm 0.3$ & $3 / 2$ & $0.12 \pm 0.02$ \\
\hline reac006n & $0.5 \pm 0.3$ & $8.9 \pm 5.3$ & $0.20 \pm 0.05$ & $4 / 2$ & $0.02 \pm 0.01$ \\
\hline reac $002 a$ & $0.25 \pm 0.05$ & $6.7 \pm 2.1$ & n.d. & - & - \\
\hline reac008 & $0.27 \pm 0.04$ & $7.0 \pm 1.0$ & $0.3 \pm 0.01$ & $1 / 1$ & 0.03 \\
\hline reac003 & $2.1 \pm 0.5$ & $60.6 \pm 27.5$ & $1.51 \pm 0.05$ & $2 / 2$ & $0.11 \pm 0.05$ \\
\hline reac $003 n$ & $2.4 \pm 0.7$ & $64.8 \pm 17.9$ & $1.44 \pm 0.03$ & $2 / 2$ & $0.11 \pm 0.01$ \\
\hline reac009 & $0.9 \pm 0.1$ & $18.8 \pm 8.8$ & n.d. & - & - \\
\hline reac002bn & $0.28 \pm 0.04$ & $6.3 \pm 0.7$ & n.d. & - & - \\
\hline reac $002 b$ & $0.25 \pm 0.02$ & $6.2 \pm 0.7$ & n.d. & - & - \\
\hline
\end{tabular}

The growth rates are calculated from the measured weight increases of the calcite crystals during the growth experiments (Table 2). The $\mathrm{Sr} / \mathrm{Ca}$ molar ratios are derived from the LA-ICP-MS measurements. The number of measurements $\left(n_{\mathrm{m}}\right)$, as well as the number of crystals $\left(n_{\mathrm{c}}\right)$ grown per inflow solution composition, are given (n.d., not determined). 


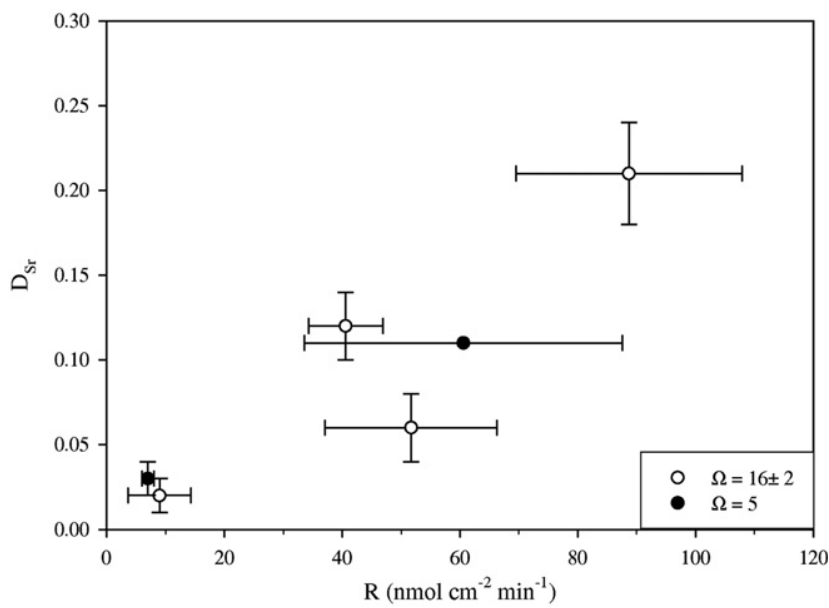

Fig. 6. Distribution coefficient for $\mathrm{Sr}$ versus calcite growth rate for two different degrees of supersaturation (error bars denote standard deviations)

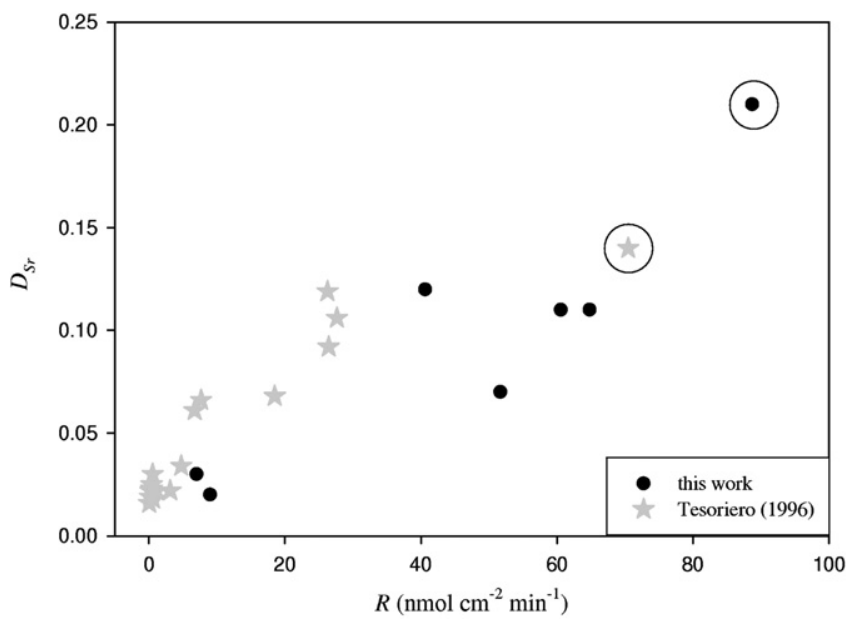

Fig. 7. Comparison of $D_{\mathrm{Sr}}$ values obtained in this study and in Tesoriero and Pankow (1996), plotted versus the calcite growth rates normalized to the surface areas of the seed materials. The encircled data points may be affected by the precipitation of $\mathrm{SrCO}_{3}$. See text for detailed discussion.

\section{CONCLUSIONS}

Calcite growth experiments carried out at constant $\mathrm{pH}$ and supersaturation demonstrate that the growth kinetics depend on solution stoichiometry. The growth rate is maximal in a stoichiometric solution, i.e., when $r=\left[\mathrm{Ca}^{2+}\right] /$ $\left[\mathrm{CO}_{3}{ }^{2-}\right]=1$, and decreases symmetrically away from $r=1$. The effect of solution stoichiometry is most pronounced for values of $r$ between 0.1 and 10. Within this range, an increasing departure from $r=1$ may lead to a decrease in the growth rate, even if the degree of supersaturation of the solution actually increases. The symmetric rate distribution around $r=1$ suggests similar frequency factors for the attachment of cation and anion to kink sites at the mineral surface, under the high $\mathrm{pH}$ (10.2) conditions of this study.

The incorporation of strontium in calcite increases with increasing growth rate. The $\mathrm{Sr}$ distribution coefficients obtained here for single crystals are consistent with values in earlier studies using suspended calcite powders, when normalizing the growth rate to the geometric calcite surface area. The $\mathrm{Sr} / \mathrm{Ca}$ ratio in calcite thus reflects the combined effects of the supersaturation and stoichiometry of the aqueous phase on the crystal growth kinetics. Both supersaturation and solution stoichiometry at the site of calcite formation are potentially modulated by cellular processes in calcifying organisms, and may therefore contribute to the "vital effect" on $\mathrm{Sr} / \mathrm{Ca}$ ratios.

\section{ACKNOWLEDGMENTS}

The authors thank Don Rimstidt and two anonymous reviewers for helpful and constructive comments and suggestions. We also thank Alfonso Mucci for revisions and corrections that improved the manuscript during the review process. This work was supported by the German research foundation (DFG) and the Netherlands Organisation for Scientific Research (NWO), within the framework of the German/Dutch project BI 432/3-1 and 2 ("Procycal") and BI 
432/4-2 ("PaleoSalt"), and by the European Science Foundation (ESF) under the EUROCORES Programmes EuroCLIMATE and EuroMinScI through contract No. ERAS-CT-2003-980409 of the European Commission, DG Research, FP6. CM acknowledges a fellowship that provided financial support and hospitality at the "Hanse Institute for Advance Study, Delmenhorst" in corporation with the Alfred Wegener Institute, Bremerhaven.

\section{REFERENCES}

Boyle E. A. (1981) Cadmium, zinc, copper, and barium in foraminifera tests. Earth Planet. Sci. Lett. 53, 11-35.

Boyle E. A. (1988) Cadmium: chemical tracer of deepwater paleoceanography. Paleoceanography 3, 471-489.

Cai W.-J., Zhao P., and Wang Y. (2000) pH and pCO2 microelectrode measurements and the diffusive behavior of carbon dioxide species in coastal marine sediments. Mar. Chem. 70, 133-148.

Chernov A. A. (2001) Crystal growth science between the centuries. J. Mater. Sci.-Mater. Electron. 12, 437-449.

Chernov A. A., Petrova E. V., and Rashkovich L. N. (2006) Dependence of the $\mathrm{CaOx}$ and $\mathrm{MgOx}$ growth rate on solution stoichiometry. Non-Kossel crystal growth. J. Cryst. Growth 289, 245-254.

Christoffersen J., and Christoffersen M. R. (1990) Kinetics of spiral growth of calcite crystals and determination of the absolute rate constant. J. Cryst. Growth 100, 203-211.

Curti E. (1997) Coprecipitation of radionuclides: basic concepts, literature review and first applications. PSI-Bericht Nr., 10-97.

Gustafsson J. P. (2004) Visual Minteq ver. 2.40. KTH, (http:// www.lwr.kth.se/English/OurSoftware/vminteq/index.htm), Stockholm, Sweden.

Jackson S. E., Longerich H. P., Dunning G. R., and Fryer B. J. (1992) The application of laser-ablation microprobe-inductively coupled plasma-mass spectrometry (LAM-ICP-MS) to in situ trace element determination in minerals. Can. Mineral. 30, 1049-1064.

Jahnke R. A., and Jahnke D. B. (2004) Calcium carbonate dissolution in deep sea sediments: Reconciling microelectrod, pore water and benthic flux chamber results. Geochim. Cosmochim. Acta 68(1), 47-59.

Kitano Y., and Oomori T. (1971) The coprecipitation of uranium with calcium carbonate. J. Oceanogr. Soc. Japan 27, 34-42.

Kitano Y., Kanamori N., and Oomori T. (1971) Measurements of distribution coefficients of strontium and barium between precipitate and solution - abnormally high values of distribution coefficients measured at early stages of carbonate formation. Geochem. J. 4, 183-206.

Kossel W. (1927) Zur Theorie des Kristallwachstums. Nachrich. Ges. Wiss. Göttingen, Math.-phys. Klasse, 135-143.

Langer G., Gussone N., Nehrke G., Riebesell U., Eisenhauer A., Kunert H., Rost B., Trimborn S., and Thoms S. (2006) Coccolith strontium to calcite ratios in Emiliania huxleyi: the dependence on seawater strontium and calcium concentrations. Limnol. Oceanogr. 51, 310-320.

Langmuir D. (1997) Aqueous Environmental Geochemistry. Prentice Hall.

Lasaga A. C., and Lüttge A. (2005) Kinetic justification of the solubility product: application of a general kinetic dissolution model. J. Phys. Chem. B 109, 1635-1642.

Lea D., and Boyle E. (1989) Barium content of benthic foraminifera controlled by bottom-water composition. Nature 338, 751-753.

Lebron I., and Suarez D. L. (1998) Kinetics and mechanisms of precipitation of calcite as affected by $\mathrm{P}_{\mathrm{CO} 2}$ and organic ligands at $25^{\circ}$ C. Geochim. Cosmochim. Acta 62, 405-416.
Lemarchand D., Wasserburg G. J., and Papanastassiou D. A. (2004) Rate-controlled calcium isotope fractionation in synthetic calcite. Geochim. Cosmochim. Acta 68, 4665-4678.

Lorens R. B. (1981) Sr, Cd, Mn and Co distribution coefficients in calcite as a function of calcite precipitation rate. Geochim. Cosmochim. Acta 45, 533-561.

Mank A. G. K., and Mason P. R. D. (1999) A critical assessment of laser ablation ICP-MS as an analytical tool for depth analysis in silica-based glas samples. J. Analyt. Atom. Spectrosc. 14, 1141-1153.

Markov I. V. (2003) Crystal Growth for Beginners. World Science Publishing Co. Pte. Ltd.

Mason P. R. D., and Kraan W. J. (2002) Attenuation of spectral interferences during laser ablation inductively coupled plasma mass spectroscopy (LA-ICP-MS) using an rf only collision and reaction cell. J. Analyt. Atom. Spectrosc. 17, 858-867.

McIntire W. L. (1963) Trace element partition coefficients-a review of theory and applications to geology. Geochim. Cosmochim. Acta 27, 1209-1264.

Morse J. W., and Bender M. L. (1990) Partition coefficients in calcite: examination of factors influencing the validity of experimental results and their application to natural systems. Chem. Geol. 82, 265-277.

Morse J. W., and Mackenzie F. T. (1990) Geochemistry of Sedimentary Carbonates. Elsevier, Amsterdam.

Mucci A. (1986) Growth kinetics and composition of magnesian calcite overgrowth precipitated from seawater: quantitative influence of orthophosphate ions. Geochim. Cosmochim. Acta 50, 2253-2265.

Mucci A., and Morse J. W. (1983) The incorporation of $\mathrm{Mg}^{2+}$ and $\mathrm{Sr}^{2+}$ into calcite overgrowths: influences of growth rate and solution composition. Geochim. Cosmochim. Acta 47, 217-233.

Mueller B., Wang Y., Dittrich M., and Wehrli B. (2003) Influence of organic carbon decomposition on calcite dissolution in surficial sediments of a freshwater lake. Water Res. 37, $4524-4532$.

Nancollas G. H., and Reddy M. M. (1971) The crystallization of calcium carbonate. II. Calcite growth mechanism. J. Colloid Interface Sci. 37, 824-830.

Nielsen A. E. (1964) Kinetics of Precipitation. Pergamon Press.

Nielsen A. E. (1984) Electrolyte crystal growth mechanism. J. Crystal Growth 67, 289-310.

Nielsen A. E., and Toft J. M. (1984) Electrolyte crystal growth kinetics. J. Crystal Growth 67, 278-288.

Nilsson O., and Sternbeck J. (1999) A mechanistic model for calcite crystal growth using surface speciation. Geochim. Cosmochim. Acta 63, 217-225.

Pearce N. J. G., Perkins W. T., Westgate J. A., Gorton M. P., Jackson S. E., Neal C. R., and Chenery S. P. (1997) A compilation of new and published major and trace element data for NIST SRM 610 and NIST SRM 612 glass reference materials. Geostandards Newslett. 21, 115-144.

Pingitore N. E., and Eastman M. P. (1984) The experimental partitioning of $\mathrm{Ba}^{2+}$ into calcite. Chem. Geol. 45, 113-120.

Rimstidt J. D., Bolag A., and Webb J. (1998) Distribution of trace elements between carbonate minerals and aqueous solutions. Geochim. Cosmochim. Acta 62, 1851-1863.

Sawada K. (1998) Mechanisms of crystal growth of ionic crystals in solution. Formation, transformation, and growth inhibition of calcium carbonates. In Crystallization Processes (ed. H. Ohtaki). John Wiley \& Sons.

Sternbeck J. (1997) Kinetics of rhodochrosite crystal growth at $25^{\circ} \mathrm{C}$ : the role of surface speciation. Geochim. Cosmochim. Acta 61, 785-793.

Stoll H. M., Rosenthal Y., and Falkowski P. (2002) Climate proxies from $\mathrm{Sr} / \mathrm{Ca}$ of coccolith calcite: calibrations from 
continuous culture of Emiliania huxleyi. Geochim. Cosmochim. Acta 66, 927-936.

Stranski I. N. (1928) Zur Theorie des Kristallwachstums. Zeitschrift für physikalische Chemie (Leipzig) 136, 259-278.

Temmam M., Paquette J., and Vali H. (2000) Mn and $\mathrm{Zn}$ incorporation into calcite as a function of chloride aqueous concentration. Geochim. Cosmochim. Acta 64, 2417-2430.

Teng H. H., Dove P. M., and Yoreo J. J. (2000) Kinetics of calcite growth: surface processes and relationships to macroscopic rate laws. Geochim. Cosmochim. Acta 64, 2255-2266.

Tesoriero A. J., and Pankow J. F. (1996) Solid solution partitioning of $\mathrm{Sr}^{2+}, \mathrm{Ba}^{2+}$, and $\mathrm{Cd}^{2+}$ to calcite. Geochim. Cosmochim. Acta 60, 1053-1063.

Van Cappellen P., Charlet L., Stumm W., and Wersin P. (1993) A surface complexation model of the carbonate mineral-aqueous solution interface. Geochim. Cosmochim. Acta 57, 3505-3518.

van der Weijden R. D., van der Heijden A. E., Witkamp G. J., and van Rosmalen G. M. (1997) The influence of total calcium and total carbonate on the growth rate of calcite. J. Crystal Growth 171, 190-196.

Watson E. B. (1996) Surface enrichment and trace-element uptake during crystal growth. Geochim. Cosmochim. Acta 60, 50135020 .

Watson E. B., and Liang Y. (1995) A simple model for sector zoning in slowly grown crystals: Implications for growth rate and lattice diffusion, with emphasis on accessory minerals in crustal rocks. Am. Mineral. 80, 1179-1187.

Winter D. J., and Burton E. A. (1992) Experimental investigation $\mathrm{a}_{\mathrm{Ca}} / \mathrm{a}_{\mathrm{CO} 3}$ ratio on the kinetics of calcite precipitation: implication for the rate equation and trace element incorporation. $G S A$ Abstr. Preg $A 37$ (abstr.).

Zeebe R. E., and Westbroek P. (2003) A simple model for the $\mathrm{CaCO} 3$ saturation state of the ocean: The "Strangelove", the "Netitan", and the "Cretan" Ocean. Geochem. Geophys. Geosyst. 4(12), 1104, doi:10.1029/2003GC000538.

Zhang J., and Nancollas G. H. (1990) Kink densities along a crystal surface step at low temperatures and under nonequilibrium conditions. J. Crystal Growth. 106, $181-190$

Zhang J., and Nancollas G. H. (1998) Kink density and rate of step movement during growth and dissolution of an $\mathrm{AB}$ crystal in a nonstoichiometric solution. J. Colloid Interface Sci. 200, 131-145.

Zuddas P., and Mucci A. (1994) Kinetics of calcite precipitation from seawater: I. a classical chemical kinetics description for strong electrolyte solutions. Geochim. Cosmochim. Acta 58, $4353-4362$.

Associate editor: Alfonso Mucci 